Available online at GSC Online Press Directory

GSC Biological and Pharmaceutical Sciences

e-ISSN: 2581-3250, CODEN (USA): GBPSC2

Journal homepage: https://www.gsconlinepress.com/journals/gscbps

(RESEARCH ARTICLE)

\title{
Alternaria diseases of agricultural crops in Uzbekistan
}

Gulchehra Kulmuminovna Khalmuminova ${ }^{1,}$, Shukhrat Ganievich Kamilov ${ }^{2}$, Olga Antonovna Verushkina ${ }^{3}$ and Mutabar Kushakovna Khujanazarova ${ }^{3}$

\author{
${ }_{1}^{1}$ PhD, Senior Teacher of the Department of Agrobiotechnology, Tashkent State Agrarian University, Tashkent, \\ Uzbekistan. \\ ${ }^{2}$ Candidate of Biological Science, Associate Professor of the Department of Agrobiotechnology, Tashkent State Agrarian \\ University, Tashkent, Uzbekistan. \\ ${ }^{3}$ Assistant of the Department of Agrobiotechnology, Tashkent State Agrarian University, Tashkent, Uzbekistan.
}

Publication history: Received on 30 October 2020; revised on 08 November 2020; accepted on 10 November 2020

Article DOI: https://doi.org/10.30574/gscbps.2020.13.2.0353

\begin{abstract}
In the article the tasks have been set on the inventory of the species composition of fungi of the genus Alternaria Nees ex Walroth - pathogen of various Alternaria diseases of vegetable crops in Uzbekistan. More than 200 isolates were collected and about 150 monosporous pure cultures were obtained from them. According to preliminary data, they belong to 15 species of the genus Alternaria and have been isolated from the 12 most important crop species. It was found that a more accurate identification of species requires the study of a wide range of morphological and biochemical traits. The article discusses the issue of infection of vegetable seeds in Uzbekistan. The composition of micromycetes living on seeds of vegetable and green crops was revealed. In total, 21 species were recorded, of which 9 species includes to Alternaria genus.
\end{abstract}

Keywords: Alternaria; Micromycetes; Leaf spot; Disease; Seed infection; Conidiophores; Conidia.

\section{Introduction}

Fungi of the genus Alternaria Nees ex Walroth are widespread in nature. Due to their wide ecological amplitude, they have adapted to parasitism on various important crops. Diseases of various cultivated, wild-growing and weed plants, called Alternaria, are known to all phytopathologists and the staff of the plant protection system. Species of this genus are found all over the world. Some of them are harmless saprotrophs, while others, parasitic species, cause harmful diseases of crops.

The identification of many micromycetes and, in particular, Alternaria species is associated with a number of difficulties, such as the similarity of morphological characteristics of different species and, at the same time, intraspecific variability of traits.

Many Alternaria species cause leaf spots and thereby damage the photosynthetic apparatus of the plant, which, if severely infested, leads to significant yield losses, especially in weakened plants of susceptible varieties. It is estimated that the loss of tomato fruit yield in India reached 78\% [1]. Studies carried out in Germany have shown that the loss of yield of winter rapeseeds from Alternaria can be up to $50 \%$ [2]. The dying off of carrot tops caused by Alternaria greatly reduces the efficiency of mechanized harvesting of root crops $[3,4]$.

\footnotetext{
* Corresponding author: Khalmuminova Gulchehra Kulmuminovna

$\mathrm{PhD}$, Senior Teacher of the Department of Agrobiotechnology, Tashkent State Agrarian University, Tashkent, Uzbekistan. 
Alternaria species have been identified on a very wide range of plant substrates. Some species are saprotrophs, but most are parasites with a necrotrophic feeding method and various specializing and degree of parasitism (from facultative parasites to facultative saprotrophs).

The disease is widely known in Uzbekistan as spotting of potatoes and tomatoes. Alternaria on potatoes and tomatoes in open ground caused by large-spore Alternaria species (A. solani in a wide sense). Alternaria of cruciferous crops (cabbage, rapeseed, radish, etc.) caused by A. brassicae, A. brassicicola, and A. japonica (syn. A. raphani) is widespread everywhere. Alternaria on leaves and root crops of carrots (A. dauci, A. radicina) has been identified in several regions of Uzbekistan. The spread of Alternaria at the end of the growing season before harvesting reaches $90-100 \%$, and development up to $15 \%$. Alternaria on onions (A. porri), pumpkin (A. cucumerina) and a number of ornamental plants (calendula, zinnia) are of local importance.

The genus Alternaria, previously attributed to imperfect fungi (Hyphomycetes species, Dematiaceae family), in accordance with the currently accepted system, is considered an anamorph of marsupial fungi of the Pleosporaceae family of the order Pleosporales of the Pleosporomycetidae subclass of the Dothideomycetes class [5]. In some Alternaria species, a teleomorph (sexual stage) from the genus Lewia is known, but the vast majority of species have lost it.

It is known that the disease Alternaria can be transmitted by seeds, in this regard, we conducted a study to identify the possibility of transmission of infection by seeds [6]. Sometimes such an infection is not accompanied by the appearance of any symptoms and does not lead to a decrease in the number of seeds and their quality (weight of 1000 seeds, germination). In other cases, the damage from infection is very significant and manifests itself in hollow seed, low viability. During the period of seed germination, the fungus, under favorable conditions for it, can release phytotoxins that reduce germination. Also, seed infection sometimes leads to infection of seedlings and their death. The detrimental effect of seed infection with Alternaria species on seedlings of cruciferous crops [7], flax [8], carrots [9], and other agricultural plants has been described.

\section{Material and methods}

The collection of material was carried out during a route survey on sowing of agricultural crops in farms and in vegetable stores of Tashkent region. Also studied herbarium samples of affected plants stored in the mycological herbarium of the Institute of Botany of the Academy of Sciences of Uzbekistan.

The identification was carried out according to the monographs by M.B. Ellis [10, 11], L.M. Levkina [12], F.B. Gannibal [13]. Reconciliation was done according to the work of M.Sh. Sagdullaeva et al. [14].

\section{Results}

The aim of this work is to study the representation of various Alternaria species associated with agricultural crops for further analysis of morphological and other identification traits. Within the Republic of Uzbekistan, the species of the genus Alternaria have been little studied, and their identification was carried out mainly on the basis of specialization to certain substrates and distribution [14]. The analysis of the species composition of the pathogens of Alternaria in vegetable crops has not been carried out yet taking into account the modern taxonomic concepts. Many Alternaria species cause serious disease in important crops. Carrots (black rot and brown spot), crucifers (black spot), potatoes (early spot), grain crops (black embryo or asymptomatic lesion of kernels) suffer especially strongly from Alternaria.

The work has been carried out since 2011. In the course of the research, the crops of grain, vegetables and cotton were examined. In addition to more than 200 strains we collected, the work involved materials stored in the mycology laboratory of the Institute of Botany of the Academy of Sciences of the Republic of Uzbekistan and the experimental station of the Tashkent Agrarian University.

A preliminary analysis of about 150 collected strains by obtaining monosporous pure cultures, showed that they belong to the following species.

- $\quad$ Lycopersicum esculentum (tomato) - A. alternata (Fr.) Keissler .f. sp. lycopersici (black mold on fruits); $A$. longipes (Ell. Et Ev.), Wasson (alternaria), A. solani (Ell. Et Mart.) Sor.;

- Solanum tuberosum (potato) - A.solani (Ell. Et Mart.) Sor. (alternaria), A. alternata (Fr.) Keissel (alternaria), $A$. tenuissima (Kunze ex Pers.) Wiltshire; 
- $\quad$ Daucus carota (carrot) - A. radicina Meier, Drecshler \& Eddy; (black rot), A. dauci (Kuhn) Groves \& Skolko, A. alternata (Fr.) Keissel;

- Allium cepa (onion) - A. porri (Ell.) Cif., A. alternata (Fr.) Keissel;

- Brassica oleraceae (cabbage) - A. brassicae Sacc., A. brassicola (Schw.) Wiltshire, A. japonica Yoshii (alternaria);

- $6 . \quad$ Capsicum annuum (pepper) -A. solani (Ell. Et Mart.) Sor. (Alternaria of pepper fruit), A. alternata (Fr.) Keisse;

- Solanum melongena (eggplant) - A. solani (Ell. Et Mart.) Sor.;

- Cucurbita pepo (pumpkin) - A.cucumerina (Ellis \& Everh.) Elliot (leaf spot and wilting), A. longissima Deigthon \& MacGarvie, A. alternata (Fr.) Keisse;

- Apium graveolens, Anethum graveolens (celery, dill) - A.radicina Meier, Drecshler \& Eddy;

- $\quad$ Triticum aestivum (wheat) - A. alternata (Fr.) Keissel (black embryo), A. state of Pleospora infectoria Fuckel;

- Cotton plant - A. macrospora Zimm.

- Helianthus annuus (sunflower) - Alternariaster helianthi (Hansf.) E.G. Simmons (syn. A. helianthi).

21 species of phytopathogenic fungi were identified from vegetable seeds, where, along with the genus Alternaria (9 species), the species frequently found on many plants were distinguished: p.p. Aspergillus, Botrytis, Chaetomium, Cladosporium, Fusarium, Mucor, Helmintosporium, Penicillium, Stemphillium, Trichotecium, Verticillium.

The identified types of the genus Alternaria can be classified as plant-specific pathogens. Thus, the species Alternaria alternata, A. alternata f. sp lycopersici, A.tenuissima, A.solani were found in tomato seeds, A. alternata was also found on eggplant seeds, and $A$. solani also lives on potato seeds. On cabbage seeds, A. brassica and A. brassicola were noted, which were also isolated from rapeseeds, and $A$. brassicola was also isolated from radish. A.radicina was isolated from the seeds of carrots, radishes and dill. The species $A$. dauci was also recorded on carrots. The species $A$. porri was isolated from onion seeds (Table 1).

Table 1 Micromycetes, identified in seeds of vegetable crops.

\begin{tabular}{|c|c|c|c|c|c|c|c|c|c|c|c|c|c|c|c|c|}
\hline \multirow[b]{2}{*}{ No. } & \multirow[b]{2}{*}{ Micromycetes species } & \multicolumn{15}{|c|}{ Vegetable and green crops } \\
\hline & & 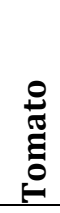 & $\begin{array}{l}0 \\
\stackrel{乛}{*} \\
\stackrel{0}{0} \\
0\end{array}$ & 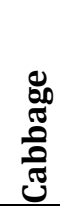 & 苛 & 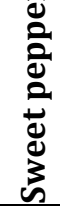 & 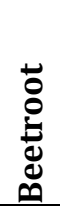 & 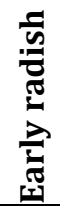 & 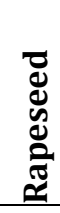 & $\begin{array}{l}\frac{\pi}{2} \\
\frac{\pi}{\pi}\end{array}$ & $\frac{\overrightarrow{0}}{\tilde{\omega}}$ & 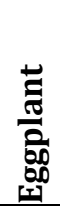 & 。ే & $\overline{\bar{a}}$ & $\frac{\overrightarrow{0}}{0}$ & 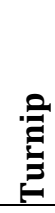 \\
\hline 1. & Alternaria alternata & + & & & & & & & & & & + & & & & \\
\hline 2. & $\begin{array}{l}\text { A. alternata f. } \quad \text { sp } \\
\text { lycopersici }\end{array}$ & + & & & & & & & & & & & & & & \\
\hline 3. & A.tenuissima & + & & & & & & & & & & & & & & \\
\hline 4. & A.solani & + & + & & & & & & & & & & & & & \\
\hline 5. & A.brassicae & & & + & & & & & + & & & & & & & \\
\hline 6. & A.brassicola & & & + & & & & + & + & & & & & & & \\
\hline 7. & A.radicina & & & & + & & & + & & & & & & + & & \\
\hline 8. & A.porri & & & & & & & & & & & & + & & & \\
\hline 9. & A.dauci & & & & + & & & & & & & & & & & \\
\hline 10. & Aspergillus niger & + & + & + & + & & + & & & + & + & + & & + & + & \\
\hline 11. & Botrytis cinerea & & + & & + & & + & & & & & & & & & \\
\hline 12. & Chaetomium sp. & & & & & & & & + & & & & & & & \\
\hline 13. & Cladosporium herbarum & & + & + & + & & + & & & & & & & + & + & + \\
\hline 14. & Fusarium solani & & + & + & & & & + & & & & & & & & \\
\hline 15. & F.lateritium & + & & & & & & & & & & & & & & \\
\hline 16. & Mucor mycedo & + & + & + & + & & + & & + & & & + & & + & + & \\
\hline 17. & Helmintosporium sp & + & + & & & + & & & & + & + & & & & & \\
\hline 18. & Penicilium glaucum & + & + & + & + & + & + & & & & + & + & & + & + & \\
\hline 19. & Stemphilium $s p$ & + & + & & + & & & & & & & & & & & \\
\hline 20. & Trichotecium roseum & + & + & + & + & + & + & + & & + & + & + & & + & + & + \\
\hline 21. & Verticillium lateritium & + & + & + & + & + & + & + & & & + & + & & + & + & + \\
\hline
\end{tabular}




\section{Discussion}

Alternaria species have been identified on a very wide range of plant substrates. Some species are saprotrophs, but most are parasites with a necrotrophic feeding method and various specializing and degree of parasitism (from facultative parasites to facultative saprotrophs). As a result of the study, 15 species of micromycetes related to the genus Alternaria noted on 12 crops. Alternaria alternata was identified on potato, tomato, sweet pepper crops, A. alternata f. sp lycopersici only on tomatoes, A. brassica on cabbage, A. brassicola on cabbage, turnip, early radish, radishes, A. capsici-annui on sweet pepper, $A$. dauci and $A$. radicina on carrot, $A$. raphani on cabbage and radish, $A$. porri on onion, $A$. solani on potatoes, tomatoes, eggplant, beetroot, and A. tenuissima were found on tomato and potatoes.

The frequently found species with high degree development of disease are: Alternaria alternata, A. solani, A. tenuissima, the species with medium degree development are $A$. brassicae, A. brassicola, $A$. dauci, $A$. radicina, $A$. raphani, $A$. porri and less found species are A. alternata f. sp lycopersici, $A$. capsici-annui.

The taxonomy of the genus Alternaria Nees and other genera closely related to it has undergone numerous major revisions over almost 200 years. At the moment, the basis of the taxonomy of the genus is the works of E. Simmons, who published the identification key [15]. The differentiation of species according to E. Simmons is based solely on morphological traits. In our opinion, the works of M.B. Ellis [10,11] made a great contribution to the possibility of identifying fungi with mural spores. However, due to the accumulation of the level of knowledge in molecular biology and general trends in the technology of identification of living organisms, at present, much attention is paid to modern methods of studying DNA. These methods include PCR with specific primers (including quantitative real-time PCR), DNA sequencing, and enzyme-linked immunosorbent assay (ELISA) [13]. According to V.F., Hannibal (2011), it is more expedient to discuss not one genus Alternaria, but in general the entire group of fungi close in terms of kinship Alternaria hyphomycetes. Alternaria hyphomycetes includes 10 genera with a total volume of about 350 species [13]: Alternaria (about 280 species), Alternariaster (1 species), Brachycladium (2 species), Chalastospora (1 species), Embellisia (23 species), Nimbya (17 species), Prathoda (1 species), Teretispora (1 species), Ulocladium (24 species), Undifilum (2 species).

Previously, we carried out work to differentiate morphologically similar genera of micromycetes with mural spores. The identification of representatives of the genus Altenaria Nees ex Fr., Stemphyium Wallrot, and Ulocladiun Preuss presents certain difficulties due to their morphological similarity. The appearance of data on several types of conidiogenesis [16] and the recognition of their taxonomic value [17] gave impetus to the development of a new technique for identifying deuteromycetes, forcing researchers to pay attention to the existence of a conidiogenic cell, the nature of conidia formation and proliferation (germination) of conidiophoids. Despite the existing differences in the morphology of conidia of the indicated genera $[18,19,20]$, in particular: the presence of chains of spores and apical outgrowth (beak) in Altenaria conidia and the absence of those in Stemphyilum [21]; the presence of the main, medium transverse septum in Stemphylium and its absence in Ulocladium (synonym - Pseudostemphylium) [22], ignoring the features of the sporulation apparatus, can lead to an incorrect result. E.G. Simmons [23] notes the distinctive features for these genera, expressed in the outlines of conidia and proliferation of conidiophores.

In the genus Alternaria, the conidiophoid may carry one conidia or spore chain. The base of the conidia is widened, the distal end is narrowed. The ovate form is usually clearly visible at an early stage of development. The shape of the conidia of Ulogladium is different, the proximal part is narrower than the distal one. A distinctive feature is the shape of the base of the conidia and the shape of the most spores - inverted ovoid in Ulocladium as opposed to ovoid in Alternaria. The genus Stemphylium differs in the way of proliferation of the conidiophore, the shape of its apical part. The conidiogenic cell is always inflated. A single conidium forms through the terminal pore. The previously formed conidium becomes lateral or disappears. The next conidium is formed through the apex of the secondary outgrowth, and a series of 3 or more proliferations is usually observed.

It is now generally accepted to divide the species of the genus into a group of small-spore, medium- and large-spore fungi. One of the problematic group from the point of view of taxonomy, is the group of so-called small-spore Alternaria species. Previously, all representatives of this group of small-spore species were often united under one name Alternaria alternata (syn. A. tenuis). A number of attempts to describe the forms or to divide this species into smaller species, slightly differing morphologically, but specialized in different hosts (without proper experimental evidence) have led to the fact that now there are more than 100 names, estimated as small-spore taxa with unclear species characteristics that do not allow distinguish them from each other [15. Many small-spore species (e.g. Alternaria tenuissima, A. infectoria and A. alternata) have very extensive lists of plant-hosts. At the same time, several related species are very narrowly specialized, which is associated with the ability to synthesize host-specific toxins. Among such pathogens are the causative agents of diseases of the apple tree, Japanese pear, several types of citrus fruits, 
strawberries and tomatoes. The rest (not small-spore) species are mostly confined to one or several plant species of one genus, less often several genera, but one family [24, 25].

\section{Conclusion}

As a result of the study conducted, 15 species of micromycetes were identified that are related to the genus Alternaria marked on 12 crops. The composition of micromycetes living on seeds of vegetable and green crops was revealed. In total, 21 species were recorded, of which 9 species include to the genus Alternaria. Many of the listed species differ in certain morphological and cultural features from the traits indicated in the determiners, which requires their study for a wider range of morphological and biochemical traits, using possible molecular markers.

\section{Compliance with ethical standards}

\section{Acknowledgments}

The authors acknowledge the leadership staff of Institute of Botany of the Academy of Sciences of Uzbekistan, Tashkent, Uzbekistan.

\section{Disclosure of conflict of interest}

No conflict of interest declared.

\section{References}

[1] Datar VV, Mayee CD. Assessment of losses in tomato yield due to early blight. Indian Phytopathology. 1981; 34: 191-195.

[2] Daebeler F, Amelung D, Riedel V. Untersuchungen uber die Schadwirkung der durch Alternaria spp. Verursachten Rapsschwarze an Winterraps. Wiss. Z. Wilhelm-Pieck-Univ, Rostock, Naturwiss. Reihe. 1986; 35: 52-54.

[3] Pryor BM, Davis RM, Gilbertson RL. Detection and eradication of Alternaria radicina on carrot seed. Plant Diseases. 1994; 78(5): 452-456.

[4] Pryor BM,Michailides TJ. Morphological, pathogenic, and molecular characterization of Alternaria isolates associated with Alternaria late blight of pistachio. Phytopathology. 2002; 92(4): 406-416.

[5] Kirk PM, Cannon PF, Minter DW, Stalpers JA. Ainsworth and Bisby`s Dictionary of fungi. 10th edition. CAB International. 2008; 771.

[6] Hannibal FB. Species composition, systematic and geography of the pathogen of sunflower alternaria in Russia. Bulletin Plant Protection. 2011; 1: 13-19.

[7] Maude RB Humpherson-Jones FM. Studies on the seedborne phases of dark leaf spot (Alternaria brassicicola) and grey leaf spot (Alternaria brassicae) of brassicas. Annals of Applied Biology. 1980; 95: 311-319.

[8] Evans N, McRoberts N, Hill RA, Marshall G. Phytotoxin production by Alternaria linicola and phytoalexin production by the linseed host. Annals-of-Applied-Biology. 1996; 129(3): 415-431.

[9] Coles RB, Wicks TJ. The incidence of Alternaria radicina on carrot seeds, seedlings and roots in South Australia. Australasian Plant Pathology. 2003; 32: 99-104.

[10] Ellis MB. Dematiaceous hyphomycetes. Kew, Surrey, UK, CMI. 1971; 608.

[11] Ellis MB. More dematiaceous hyphomycetes. Kew, Surrey, UK, CAB IMI. 1976; 507.

[12] Levkina LM. Taxonomy of the genus Alternaria Nees. Mycology and phytopathology. 1984; 18(1): 80-86.

[13] Hannibal FB. Monitoring of Alternaria diseases of agricultural crops and identification of fungi of the genus Alternaria. SPb. 2011; 71.

[14] Sagdullayeva, MSh, Kirgizbayeva HM, Ramazanova SS. Hyphal fungi. Flora of fungi in Uzbekistan, Vol.6, Tashkent, Fan. 1990; 132.

[15] Simmons EG. Alternaria. An Identification Manual. Utrecht: CBS. 2007; 775.

[16] Hughes SI. Conidiophores, conidia and classification. Canadian Journal of Botany. 1953; 31(5): 577-659. 
[17] Kendrick B. Taxonomy of Fungi Imperfecti. Univ. Toronto Press, Toronto. 1971.

[18] Heegaard PE. Some parasitic copepods from fishes in the Uppsala University collections. Arkiv för Zoologi (A). 1945; 35(18): 1-27.

[19] Subramanian A. Classification of the Hyphomycetes. Current Science. 1961; 31: 409-411.

[20] Litvinov MA. Determiner of microscopic soil fungi. Leningrad. 1967; 124.

[21] Wiltshire SP. The foundation species of Alternaria and Macrosporium. Transaction of British Mycological Society. 1933; 18: 135-160.

[22] Wiltshire SP. The original and modern conceptions of Stemphylium. Transactions of the British Mycological Society. 1938; 21: 211-239.

[23] Simmons EG. Typification of Alternaria, Stemphylium and Ulocladium. Mycologia. 1967; 59: 67-92.

[24] Simmons EG. Alternaria taxonomy: current status, viewpoint, challenge. Alternaria. Biology, plant diseases and metabolites. Amsterdam: Elsevier. 1992; 36.

[25] Zhang TY. Alternaria. Flora Fungorum sinicorum. Vol. 16 - Beijing: Science press. 2003; 216. 